\title{
Communication
}

\section{Investigating the Proton and Ion Transfer Properties of Supported Ionic Liquid Membranes Prepared for Bioelectrochemical Applications Using Hydrophobic Imidazolium-Type Ionic Liquids}

\author{
László Koók, Piroska Lajtai-Szabó $\mathbb{D}^{\mathrm{D}}$, Péter Bakonyi *, Katalin Bélafi-Bakó and Nándor Nemestóthy
}

Citation: Koók, L.; Lajtai-Szabó, P.; Bakonyi, P.; Bélafi-Bakó, K.; Nemestóthy, N. Investigating the Proton and Ion Transfer Properties of Supported Ionic Liquid Membranes Prepared for Bioelectrochemical Applications Using Hydrophobic Imidazolium-Type Ionic Liquids. Membranes 2021, 11, 359. https:// doi.org/10.3390/membranes11050359

Academic Editor: Giovanni Battista Appetecchi

Received: 18 April 2021

Accepted: 12 May 2021

Published: 14 May 2021

Publisher's Note: MDPI stays neutral with regard to jurisdictional claims in published maps and institutional affiliations.

Copyright: (c) 2021 by the authors. Licensee MDPI, Basel, Switzerland. This article is an open access article distributed under the terms and conditions of the Creative Commons Attribution (CC BY) license (https:/ / creativecommons.org/licenses/by/ $4.0 /)$.
Research Group on Bioengineering, Membrane Technology and Energetics, University of Pannonia, Egyetem ut 10, 8200 Veszprém, Hungary; kook@almos.uni-pannon.hu (L.K.); tpiroska94@gmail.com (P.L.-S.); bako@almos.uni-pannon.hu (K.B.-B.); nemesn@almos.uni-pannon.hu (N.N.)

* Correspondence: bakonyip@almos.uni-pannon.hu; Tel.: +36-88-624385

\begin{abstract}
Hydrophobic ionic liquids (IL) may offer a special electrolyte in the form of supported ionic liquid membranes (SILM) for microbial fuel cells (MFC) due to their advantageous mass transfer characteristics. In this work, the proton and ion transfer properties of SILMs made with IL containing imidazolium cation and $\left[\mathrm{PF}_{6}\right]^{-}$and $\left[\mathrm{NTf}_{2}\right]^{-}$anions were studied and compared to Nafion. It resulted that both ILs show better proton mass transfer and diffusion coefficient than Nafion. The data implied the presence of water microclusters permeating through $[\mathrm{hmim}]\left[\mathrm{PF}_{6}\right]-\mathrm{SILM}$ to assist the proton transfer. This mechanism could not be assumed in the case of $\left[\mathrm{NTf}_{2}\right]^{-}$containing IL. Ion transport numbers of $\mathrm{K}^{+}, \mathrm{Na}^{+}$, and $\mathrm{H}^{+}$showed that the IL with $\left[\mathrm{PF}_{6}\right]^{-}$anion could be beneficial in terms of reducing ion transfer losses in MFCs. Moreover, the conductivity of [bmim] $\left[\mathrm{PF}_{6}\right]-\mathrm{SILM}_{\mathrm{L}}$ low electrolyte concentration (such as in MFCs) was comparable to Nafion.
\end{abstract}

Keywords: ionic liquid; SILM; membrane; proton transfer; ion transport; DC conductivity

\section{Introduction}

MFCs belong to the family of bioelectrochemical technologies, where the bioelectrocatalytic activity of exoelectrogenic bacteria (EAB), which are known for their ability to transfer electrons extracellularly to the surface of an electrode, is utilized [1,2]. MFCs usually consist of an ion permeable membrane separating the electrode chambers. Generally, the membrane is proton selective (e.g., Nafion) and its main purpose is to ensure sufficient proton transport from the anode to the cathode for the reduction of an electron acceptor (most often $\mathrm{O}_{2}$ ) in line with Equation (1).

$$
\mathrm{O}_{2}+4 \mathrm{e}^{-}+4 \mathrm{H}^{+} \rightarrow 2 \mathrm{H}_{2} \mathrm{O}
$$

However, the low proton concentration in MFCs $\left(\left[\mathrm{H}^{+}\right]<10^{-6} \mathrm{M}\right)$ inherently cause deviations from Equation (1) at $\mathrm{pH}$ values close to neutral [3] and instead, the cathodic reaction formulated in Equation (2) takes place, foreshadowing the increase of catholyte $\mathrm{pH}$ (to 10-13) due to $\mathrm{OH}^{-}$formation.

$$
\mathrm{O}_{2}+4 \mathrm{e}^{-}+2 \mathrm{H}_{2} \mathrm{O} \rightarrow 4 \mathrm{OH}^{-}
$$

In addition, a general anolyte with the inocula, the buffer, and the feedstock, e.g., wastewater, contains an amount of other cations (mainly $\mathrm{Na}^{+}, \mathrm{K}^{+}, \mathrm{Mg}^{2+}, \mathrm{Ca}^{2+}$ ) 4-5 orders of magnitude higher than protons. Thus, proton transfer across the membrane can be surpassed and as a result, $\mathrm{H}^{+}$accumulates in the vicinity of the anode, the $\mathrm{pH}$ locally drops, and the inhibition of EAB may occur along with the limitation of electricity generation. 
Therefore, the development of membranes with improved charge transfer characteristics for bioelectrochemical applications such as MFCs is still a challenge. Ionic liquids (ILs) are often referred to as the green solvents and electrolytes of the future due to their excellent properties, such as negligible vapor pressure, low volatility, non-flammability, excellent thermal stability, flexible solvation features, and tunability by varying the cation/anion pairs [4-8]. Among others, they have been successfully used as non-conventional solvents for synthetic, hydrolytic, polymerization, (bio)catalytic, etc. processes [9-11]. Their use in electrochemistry focuses mostly on the heterogeneous electron-transfer processes, thanks to their good conductivity, wide viscosity range, and great electrochemical stability $[12,13]$. Moreover, ILs are used in separation technology in different forms, including membranes [14-16]. In fact, membranes containing imidazolium-type ILs could be applied effectively in MFCs by fabricating supported or polymer inclusion membranes [17-19]. It resulted that, compared to Nafion, SILMs with hydrophobic hexafluorophosphate and bis(trifluoromethylsulfonyl)imide $\left(\left[\mathrm{PF}_{6}\right]^{-}\right.$and $\left[\mathrm{NTf}_{2}\right]^{-}$) anions and 1-butyl- or 1-hexyl-3methylimidazolium $\left([\mathrm{bmim}]^{+}\right.$and $[\mathrm{hmim}]^{+}$) cations have beneficial features, including lower acetate mass transfer and diffusion coefficients, as well as lower oxygen permeation (in case of $\left[\mathrm{NTf}_{2}\right]^{-}$) [20]. It was demonstrated that MFC with SILMs based on [bmim] $\left[\mathrm{PF}_{6}\right]$ were able to outperform the Nafion-equipped ones, due to the more advantageous mass transfer-related properties (e.g., lower diffusion resistance and cathodic overpotential) [21]. Another aspect that highlights the inherent potential of ILs in this field is their antimicrobial effect $[22,23]$. This feature could play a key role in, e.g., the mitigation of biofouling, and thus, supporting more stable MFC operation and minimizing cross-membrane mass transfer-related losses. Nevertheless, this aspect should consider the IL dissolution from the membrane pores, which underlines the importance of sufficient SILM stability.

In this work, SILMs based on imidazolium-type ILs bearing $\left[\mathrm{PF}_{6}\right]^{-}$and $\left[\mathrm{NTf}_{2}\right]^{-}$ anions were investigated in terms of proton transfer characteristics, transport numbers, and ionic conductivity. The results were compared to Nafion as a reference material. To the best of our knowledge, such an approach to describe the possible proton and ion transfer behavior of SILMs made with these ILs is presented for the first time.

\section{Materials and Methods}

\subsection{Supported Ionic Liquid Membrane Preparation}

The SILMs were prepared as described in our previous works $[19,20]$. Briefly, the ILs were kept under vacuum for at least 2 days prior to use in order to get rid of water contaminants. The supporting hydrophobic PVDF with $0.22 \mu \mathrm{m}$ pore size and $75 \%$ porosity (Durapore) was pretreated under vacuum for $1 \mathrm{~h}$, then, still under vacuum, the IL (ca. $2 \mathrm{~mL}$ ) was injected to the surface of it. After at least $2 \mathrm{~h}$ of vacuuming, the surface of the obtained membranes was gently cleaned using parchment paper, and then, the membranes were weighted. In this research, $[\mathrm{bmim}]\left[\mathrm{PF}_{6}\right],[\mathrm{hmim}]\left[\mathrm{PF}_{6}\right]$, and $[\mathrm{bmim}]\left[\mathrm{NTf}_{2}\right]$ ILs were immobilized in the pores of the PVDF membrane. The main physical properties of the applied ILs can be seen in Table 1. The weight loss of ILs after vacuuming was determined, and it was systematically higher for $\left[\mathrm{PF}_{6}\right]^{-}$containing ILs ( 3-times greater loss) compared to the $\left[\mathrm{NTf}_{2}\right]^{-}$-based IL, which is in agreement with the differences in hygroscopic character of the ILs. The membranes were weighted before and after IL immobilization (and excess IL removal), and the amount of IL immobilized was found to be independent of the IL type; $300 \mathrm{mg}$ of all ILs could be introduced into the supporting membrane, resulting in $11-11.5 \mathrm{mg} \mathrm{cm}^{-2}$ IL content relative to the membrane surface area. This value fits well with previously published literature data $[18,24]$. 
Table 1. Basic data and structure of the applied ILs.

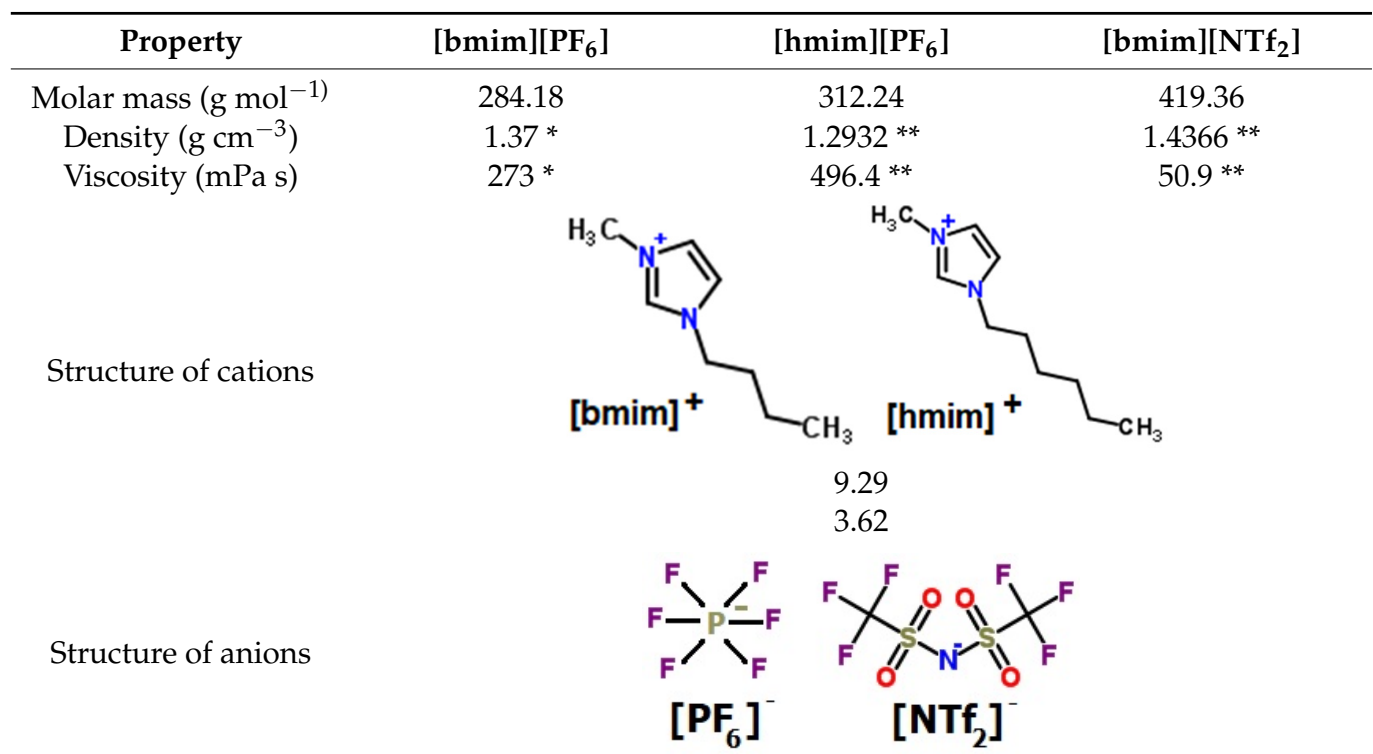

* Data based on Ref. [25], measured at $25^{\circ} \mathrm{C}$ and $0.1 \mathrm{MPa} .{ }^{* *}$ data based on Ref. [26], measured at $25^{\circ} \mathrm{C}$ and $0.1 \mathrm{MPa}$.

\subsection{Proton Transfer Characteristics}

Prior to the experiments, the Nafion115 proton exchange membrane (PEM) was preconditioned as described elsewhere [27]. A two-chambered glass reactor was deployed in the mass transfer measurements. The chambers were separated by the actual membrane (kept in deionized water for $1 \mathrm{~h}$ prior to the measurements), with a $9.62 \mathrm{~cm}^{2}$ surface area. The membranes from both sides were in contact with $55-55 \mathrm{~cm}^{3}$ liquid. Initially, one half-cell was filled with deionized water (catholyte, $\mathrm{pH}=7$ ), while the other (anolyte) was filled with deionized water and then its $\mathrm{pH}$ was set to $8.5 \mathrm{using} \mathrm{NaOH}$ [28]. The $\mathrm{pH}$ of the anolyte was continuously monitored by using a $\mathrm{pH}$ meter until one unit of $\mathrm{pH}$ change was recorded. Then, the proton mass transfer coefficient $\left(\mathrm{k}_{\mathrm{H}_{+}}\right)$was calculated according to Equation (3) [28,29],

$$
\mathrm{k}_{\mathrm{H}+}=-\frac{\mathrm{V}}{2 \mathrm{At}} \ln \left(\frac{\mathrm{c}_{1,0}+\mathrm{c}_{2,0}-2 \mathrm{c}_{2}}{\mathrm{c}_{1,0}}\right)
$$

where $\mathrm{V}$ is the volume, $\mathrm{A}_{\mathrm{M}}$ is the membrane's surface area, $\mathrm{c}_{1,0}, \mathrm{c}_{2,0}$, and $\mathrm{c}_{2}$ are the proton concentrations initially in the catholyte and anolyte, and in the anolyte at time $t$, respectively. The proton diffusion coefficient $\left(\mathrm{D}_{\mathrm{H}+}\right)$ can be calculated by taking into account the thickness of the actual membrane (d) (Equation (4)).

$$
\mathrm{D}_{\mathrm{H}+}=\mathrm{k}_{\mathrm{H}+} \mathrm{d}
$$

Considering $\mathrm{D}_{\mathrm{H}+}$, and the electric charge of a proton $\left(\mathrm{q}_{\mathrm{H}+}=1.02 \times 10^{-19} \mathrm{C}\right)$, the proton mobility $\left(\mu_{\mathrm{H}+}\right)$ was derived from the Einstein-equation (Equation (5)) [30].

$$
\mu_{\mathrm{H}+}=\frac{\mathrm{D}_{\mathrm{H}+} \mathrm{q}_{\mathrm{H}+}}{\mathrm{k}_{\mathrm{B}} \mathrm{T}}
$$

\subsection{Transport Numbers and Conductivity}

To determine the transport numbers of $\mathrm{K}^{+}, \mathrm{Na}^{+}$, and $\mathrm{H}^{+}$, a $\mathrm{H}$-cell was assembled with 250-250 mL effective chamber volumes. The given membrane was placed between the compartments. A concentration gradient was applied between the two sides of the membrane $\left(c_{1}=0.05 \mathrm{M}\right.$ and $\left.\mathrm{c}_{2}=0.01 \mathrm{M}\right)$ by using $\mathrm{KCl}, \mathrm{NaCl}$, or $\mathrm{HCl}$ solutions. $\mathrm{An} \mathrm{Ag} / \mathrm{AgCl}$ $(3 \mathrm{M} \mathrm{KCl})$ reference electrode was placed in each chamber close to the membrane surface and the potential difference $(\varphi)$ between these two electrodes was measured by a digital 
multimeter. Once $\varphi$ reached a plateau (indicating the end-point of the test), the transport number for the $\mathrm{i}$ ion $\left(\mathrm{t}_{\mathrm{i}}\right)$ was calculated according to Equation (6) [31],

$$
t_{i}=\frac{\left\{\frac{\Delta \phi F}{R T \ln \left(\frac{c_{1}}{c_{2}}\right)}+1\right\}}{2}
$$

where $\mathrm{R}$ is the universal gas constant, $\mathrm{F}$ is the Faraday's constant, and $\mathrm{T}$ is the temperature.

The DC conductivity measurements required a slightly more sophisticated setup (Figure 1), where, in addition to the two $\mathrm{Ag} / \mathrm{AgCl}$ reference electrodes at the two sides of the membrane (RE2 and RE3), both chambers were installed with a $2 \mathrm{~cm}$ long spiral Pt wire electrode $(0.5 \mathrm{~cm}$ diameter and $2 \mathrm{~mm}$ wire thickness), which played the roles of the working (WE) and counter electrodes (CE), respectively. Another $\mathrm{Ag} / \mathrm{AgCl}$ was placed next to the working electrode (RE1) in order to accomplish chronopotentiostatic control of the current flowing through the membrane, employing a PalmSens3 potentiostat/galvanostat (PalmSens BV, Houten, The Netherlands).

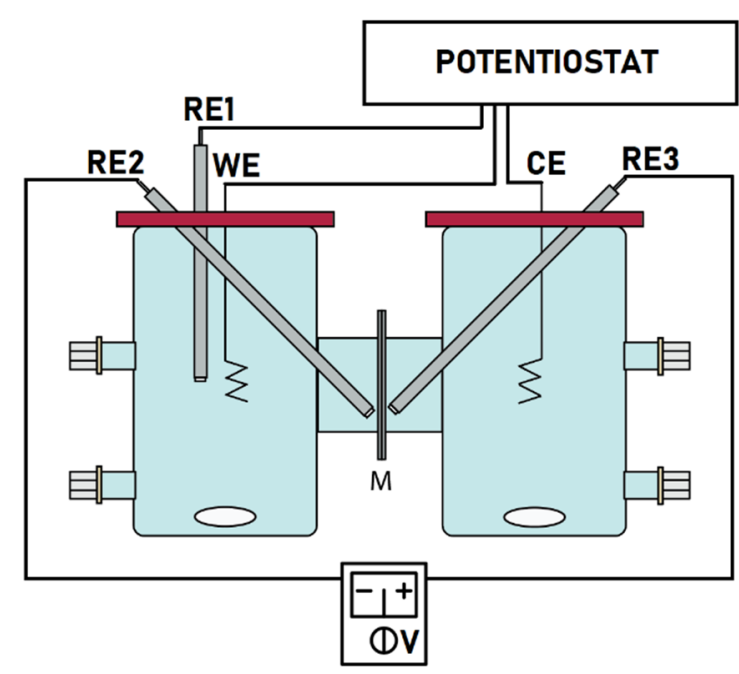

Figure 1. Experimental setup for chronopotentiostatic DC conductivity measurements.

The covered range of current density (relative to the membrane surface area) was $10^{-3}-1 \mathrm{~mA} \mathrm{~cm}^{-2}$ in accordance with practical MFC current densities [32]. The $\varphi$, similarly to the transport number measurements, was registered by a digital multimeter. The experiments were carried out at various electrolyte $(\mathrm{KCl})$ concentrations from $0.05 \mathrm{M}$ to $0.5 \mathrm{M}$. The electrolyte solutions were continuously stirred during the tests (100 rpm). To obtain the ionic conductivity, the experiments were performed in the presence and absence of the membrane. The slope of the current- $\varphi$ linear plot for the membrane-less conditions was derived from the membrane + electrolyte slopes. Conductivity $(\kappa)$ was then calculated according to Equation (7):

$$
\kappa=\left(\frac{\Delta \phi \mathrm{A}_{\mathrm{M}}}{\mathrm{Id}}\right)^{-1}
$$

where $A_{M}$ is the membrane surface area, $d$ is the membrane thickness, and I is the current.

\section{Results and Discussion}

\subsection{Proton Mass Transfer Characteristics}

The SILMs with ionic liquids of different properties, e.g., viscosity (Table 1), were prepared, in which the capillary forces arising in the pores influenced SILM stability and thus, the global mass transfer traits during operation. The rate of change in $\mathrm{pH}$ was the slowest in the case of Nafion, and the SILMs showed faster $\mathrm{pH}$ decrease (Figure 2). The one unit drop of $\mathrm{pH}$ could be observed after 7, 17, and $36 \mathrm{~min}$ in the cases of [hmim] $\left[\mathrm{PF}_{6}\right]-$ 
SILM, [bmim][NTf $\left.{ }_{2}\right]-S I L M$, and Nafion, respectively. As for Nafion, a smooth linear $\mathrm{pH}$ decrease could be observed, while the two SILMs showed a slightly different time-course. By using [bmim] $\left[\mathrm{NTf}_{2}\right]-\mathrm{SILM}$, the rate of $\mathrm{pH}$-shift apparently became more and more moderated over time after the first $6 \mathrm{~min}$. Meanwhile, after several minutes of operation, the $[\mathrm{hmim}]\left[\mathrm{PF}_{6}\right]-\mathrm{SILM}$ seemed to ensure enhanced proton transfer kinetics.

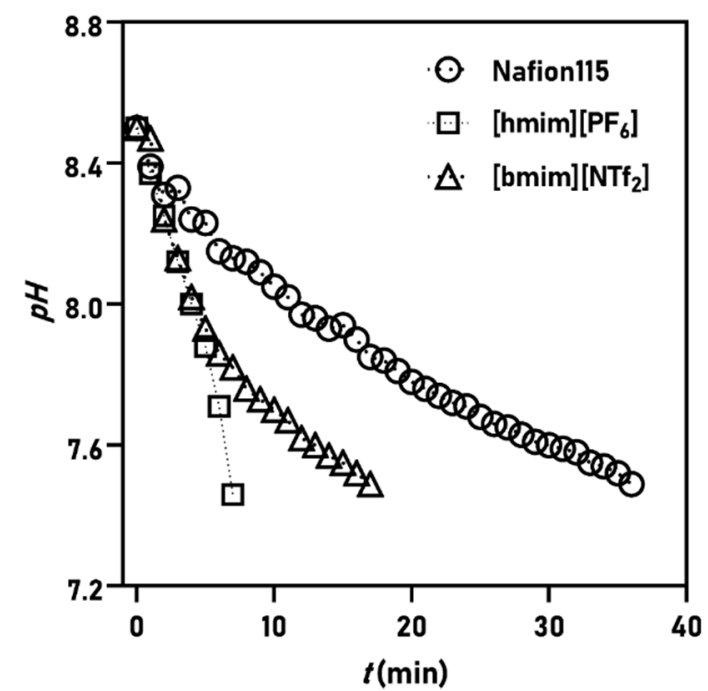

Figure 2. The change in anolyte $\mathrm{pH}$ over time using different membranes.

Based on $\mathrm{k}_{\mathrm{H}+}$ and $\mathrm{D}_{\mathrm{H}+}$, the lowest values were indeed found for Nafion, while the $\mathrm{k}_{\mathrm{H}+}$ and $\mathrm{D}_{\mathrm{H}+}$ were 2-times and $80 \%$ higher for [bmim] [NTf 2 ]-SILM and [hmim][PF 6 -SILM, respectively. The results of $[\mathrm{hmim}]\left[\mathrm{PF}_{6}\right]-$ SILM significantly exceeded the ones obtained with the other two membranes (Figure 3). These outcomes lead to several conclusions. On the one hand, the two SILMs could act as liquid electrolytes and increase the proton transfer between the anolyte and catholyte. This finding can be seen as an advantageous characteristic, in addition to the beneficial acetate and oxygen mass transfer features reported in previous publications $[19,20]$. On the other hand, by further exploring the particularly high mass transfer features of [hmim] $\left[\mathrm{PF}_{6}\right]-\mathrm{SILM}$, the mechanism of protons transfer can be understood. Based on $\mathrm{D}_{\mathrm{H}+}\left(\mathrm{D}_{\mathrm{H}+}=9.2 \times 10^{-5} \mathrm{~cm}^{2} \mathrm{~s}^{-1}\right)$, it can be noted that it makes a good match with the one measured in water at the relevant temperature $\left(D_{\mathrm{H}+}=9.3 \times 10^{-5} \mathrm{~cm}^{2} \mathrm{~s}^{-1}\right)[33,34]$. Moreover, in the $[\mathrm{hmim}]\left[\mathrm{PF}_{6}\right]-\mathrm{SILM}, \mu_{\mathrm{H}+}=3.59 \times 10^{-7} \mathrm{~m}^{2} \mathrm{~V}^{-1} \mathrm{~s}^{-1}$ was obtained, which coincides well with $\mu_{\mathrm{H}+}$ measured in water $\left(3.62 \times 10^{-7} \mathrm{~m}^{2} \mathrm{~V}^{-1} \mathrm{~s}^{-1}\right)[30,35]$.

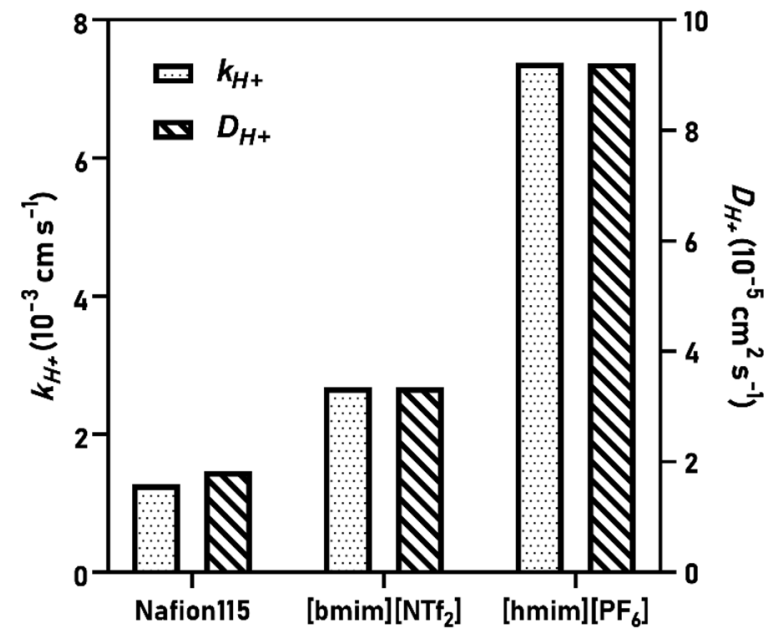

Figure 3. Proton mass transfer and diffusion coefficient values of different membranes. 
This finding indicates that water permeates through the IL and the proton transfer through the SILM is mediated by water diffusion. This is quite concurrent with previous observations in literature, where it was shown that after achieving critical water concentration in the IL, continuous water permeation could occur by microclusters through imidazolium-type ILs with $\left[\mathrm{PF}_{6}\right]^{-}$anion [36-38]. Thus, it can be deduced that protons in this IL are transferred via water microclusters as a result of the (low, but still existing) miscibility of water with the IL [39]. Among non-selective separators, this phenomenon seems quite usual, as can be seen in Table 2 where data from this work and literature sources for different separators demonstrate that proton diffusion coefficients and electric mobilities are in agreement with the values valid in water [28,40].

Table 2. Proton mass transfer coefficient, diffusion coefficient, and electric mobility of various membranes.

\begin{tabular}{|c|c|c|c|c|}
\hline Membrane & $\begin{array}{c}\mathrm{k}_{\mathrm{H}+} \\
\left(10^{-3} \mathrm{~cm} \mathrm{~s}^{-1}\right)\end{array}$ & $\begin{array}{c}\mathrm{D}_{\mathrm{H}+} \\
\left(10^{-5} \mathrm{~cm} \mathrm{~s}^{-1}\right)\end{array}$ & $\left(\begin{array}{c}\mu_{H+} \\
\left(10^{-7} \mathrm{~m}^{2} \mathrm{~V}^{-1} \mathrm{~s}^{-1}\right)\end{array}\right.$ & Ref. \\
\hline Nafion115 & 1.27 & 1.83 & 0.713 & \multirow{4}{*}{ This work } \\
\hline$[\mathrm{bmim}]\left[\mathrm{NTf}_{2}\right]$ & 2.68 & 3.35 & 1.30 & \\
\hline$[\mathrm{hmim}]\left[\mathrm{PF}_{6}\right]$ & 7.38 & 9.22 & 3.59 & \\
\hline CMI-7000 & 2.02 & 9.29 & 3.62 & \\
\hline UFM & 2.82 & 9.31 & 3.63 & \multirow[t]{2}{*}{ [40] } \\
\hline SPEEK & 4.66 & 9.32 & 3.63 & \\
\hline glass fiber & 0.94 & 9.40 & 3.66 & \multirow{2}{*}{ [28] } \\
\hline textile & 30.27 & 9.08 & 3.54 & \\
\hline
\end{tabular}

It was shown previously that the $\left[\mathrm{NTf}_{2}\right]^{-}$anion has a more hydrophobic character compared to $\left[\mathrm{PF}_{6}\right]^{-}$[41-44]. Moreover, usually the hydrophobicity is determined in a greater extent by the properties of anions rather than those of cations (e.g., slight difference in alkyl chain length) [44-47]. As for the [bmim] $\left[\mathrm{NTf}_{2}\right]$, with more significant hydrophobicity, it is assumed that water microcluster formation in the IL phase does not occur. This seems to be in line with the measured $\mathrm{k}_{\mathrm{H}}, \mathrm{D}_{\mathrm{H}_{+}}$, and $\mu_{\mathrm{H}+}$, which are notably lower relative to $[\mathrm{hmim}]\left[\mathrm{PF}_{6}\right]$. Furthermore, as $\mathrm{D}_{\mathrm{H}+}$ is two orders of magnitude higher than the diffusivity of water in [bmim] $\left.\mathrm{NTf}_{2}\right]$ [48], the transfer of protons via water microclusters is unlikely. Since $[\mathrm{bmim}]\left[\mathrm{NTf}_{2}\right]$ is an aprotic IL, the role of the acidic proton of the organic cation's imidazole ring (position 2) should not be significant (no proton exchange in the aprotic imidazole ring is presumed) [49,50], which was supported by NMR tests of [bmim][NTf $\mathrm{N}_{2}$ SILM being contacted with deuterated acetic acid (no observable $\mathrm{H}^{+}-\mathrm{D}^{+}$exchange at the spectra, data not shown). Based on this, although the question of the exact proton transfer mechanism through [bmim] $\left[\mathrm{NTf}_{2}\right]$ still remains open, it can at least be stated that the role of $\left[\mathrm{NTf}_{2}\right]^{-}$anion could be important in that matter. It was already proposed that the ion transfer in aprotic ILs proceeds via vehicle mechanism, and that the anisotropic cation-anion structure in $[\mathrm{bmim}]\left[\mathrm{NTf}_{2}\right]$ results in a wider free space for anion motion, which could play a role in proton transfer [51-53]. However, many of the conclusions are based solely on computational data, and in order to understand the mechanism, further research is needed. Nevertheless, it was shown that both ILs used in this work as SILMs ensured better proton transfer characteristics than Nafion.

\subsection{Cation Transport Numbers and Conductivity}

As the IL with $\left[\mathrm{PF}_{6}\right]^{-}$anion demonstrated significantly higher $\mathrm{k}_{\mathrm{H}+}$ and $\mathrm{D}_{\mathrm{H}+}$, it is worth investigating how these features support the MFC efficiency in a complex and varying cross-membrane ion transfer environment. As it was underlined, the high concentration of cations induces their transfer through the membrane to accomplish charge-balancing, and protons can be solely transported when it becomes energetically preferred. Accordingly, understanding the ion transfer behavior of the IL together with proton transfer 
characteristics could be useful to explain the notable efficiency of MFCs operated with SILM [21].

Therefore, ion transport numbers were sought for Nafion and SILM prepared with [bmim] $\left[\mathrm{PF}_{6}\right]$. The slight reduction in the imidazolium cation's alkyl chain length compared to $[\mathrm{hmim}]^{+}$was applied to ensure easier SILM preparation (reduced IL viscosity) and further facilitate the diffusion of certain compounds (such as water). The transport numbers were determined for $\mathrm{Na}^{+}, \mathrm{K}^{+}$, and $\mathrm{H}^{+}$. In Figure 4, the stabilization of the $\mathrm{K}^{+}$transport number using Nafion and [bmim] $\left[\mathrm{PF}_{6}\right]-\mathrm{SILM}$ is shown and the difference between $\mathrm{t}_{\mathrm{K}}$ values seem significant. A result of $t_{K_{+}} \approx 0.91$ was obtained for Nafion, which is in good agreement with its high permselectivity. However, the [bmim] $\left[\mathrm{PF}_{6}\right]-S I L M$ showed $t_{\mathrm{K}+} \approx 0.75$, indicating that $\mathrm{Cl}^{-}$ions have notably contributed to the ion transport.

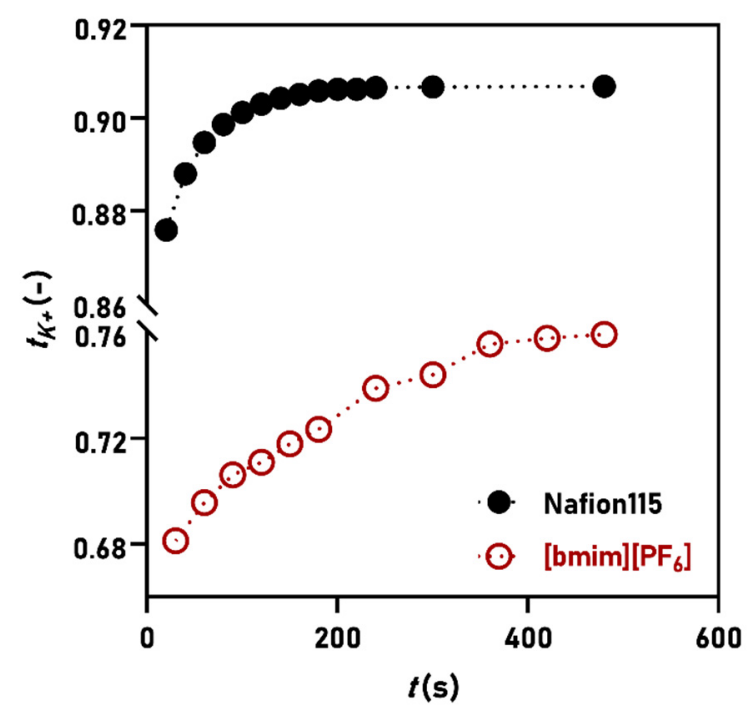

Figure 4. Time-course of $\mathrm{K}^{+}$transport numbers in the case of Nafion and [bmim] $\left[\mathrm{PF}_{6}\right]$ membranes.

Additionally, this value implies that the diffusion of ions through the SILM is not driven by any ion-selective feature of the $[\mathrm{bmim}]\left[\mathrm{PF}_{6}\right]$ and rather, it is proportional to the size of the ions in the electrolyte (the ratio of ion radii for $\mathrm{K}^{+}$and $\mathrm{Cl}^{-}$is $\mathrm{r}_{\mathrm{K}+} / \mathrm{r}_{\mathrm{Cl}-}=0.762$ ). This supports the assumption that protons-and consequently ions-transfer by the assistance of water through the IL with $\left[\mathrm{PF}_{6}\right]^{-}$.

Considering the transport numbers, Nafion reflected higher values in all cases (Table 3). The $[\mathrm{bmim}]\left[\mathrm{PF}_{6}\right]-S I L M$ exhibited a lower transport number for $\mathrm{Na}^{+}\left(\mathrm{t}_{\mathrm{Na}+}=0.761\right)$, whilst for $\mathrm{H}^{+}$, it could achieve $\mathrm{t}_{\mathrm{H}+}$ as high as $0.933\left(\mathrm{t}_{\mathrm{H}+}=0.978\right.$ for Nafion). As already stressed, MFCs equipped with Nafion may suffer from remarkable diffusion losses related to crossmembrane transfer processes [21,54]. This can be attributed to the fact that these cations migrate through the membrane instead of protons in most of the current generation phase. Nafion has great cation permselectivity, which in MFCs may be a drawback, as the rate of the ion transfer limits the performance. The findings presented so far reveal that

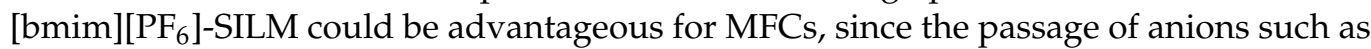
$\mathrm{Cl}^{-}$is also significant in addition to cation transfer, unlike in the case of Nafion, which may result in an increase in ion transfer rate coupled with a reduction in ion transfer losses. Moreover, the transport numbers revealed that in the sole $\mathrm{H}^{+}$-transferring stage of the MFC operation, $[\mathrm{bmim}]\left[\mathrm{PF}_{6}\right]-\mathrm{SILM}$ can satisfy the requirements of a proton exchange membrane $\left(\mathrm{t}_{\mathrm{H}+}>0.9\right)$. 
Table 3. Transport numbers of various ions in the cases of Nafion and [bmim][PF 6$]-S I L M$.

\begin{tabular}{|c|c|c|c|}
\hline Membrane & $\mathbf{t}_{\mathrm{K}+}$ & $\mathbf{t}_{\mathrm{Na}+}$ & $t_{H+}$ \\
\hline Nafion115 & 0.907 & 0.910 & 0.978 \\
\hline$[\mathrm{bmim}]\left[\mathrm{PF}_{6}\right]$ & 0.747 & 0.761 & 0.933 \\
\hline
\end{tabular}

Another feature that novel membrane materials should possess is sufficient ionic conductivity. MFCs represent a special platform in this context, since the conductivity of electrolytes is low, usually varying between 0.06 and $1 \mathrm{~S} \mathrm{~m}^{-1}$, depending on the source of the electrolyte [3]. This means that membranes ought to work efficiently even at low ion concentration. Most commercial cation exchange membranes are characterized at a standard experimental point in terms of conductivity, using $0.5 \mathrm{M} \mathrm{KCl}$ or $\mathrm{NaCl}$. Furthermore, it is known that membrane conductivity can significantly decrease by lowering the concentration, and in MFCs, the membranes are challenged by this issue. By addressing the conductivity of Nafion and [bmim] $\left[\mathrm{PF}_{6}\right]-\mathrm{SILM}$ at different electrolyte concentrations, we could conclude the superior conductivity of Nafion only at high $\mathrm{KCl}$ concentrations $\left(c_{K C l}>0.1 \mathrm{M}\right)$ (Figure 5).

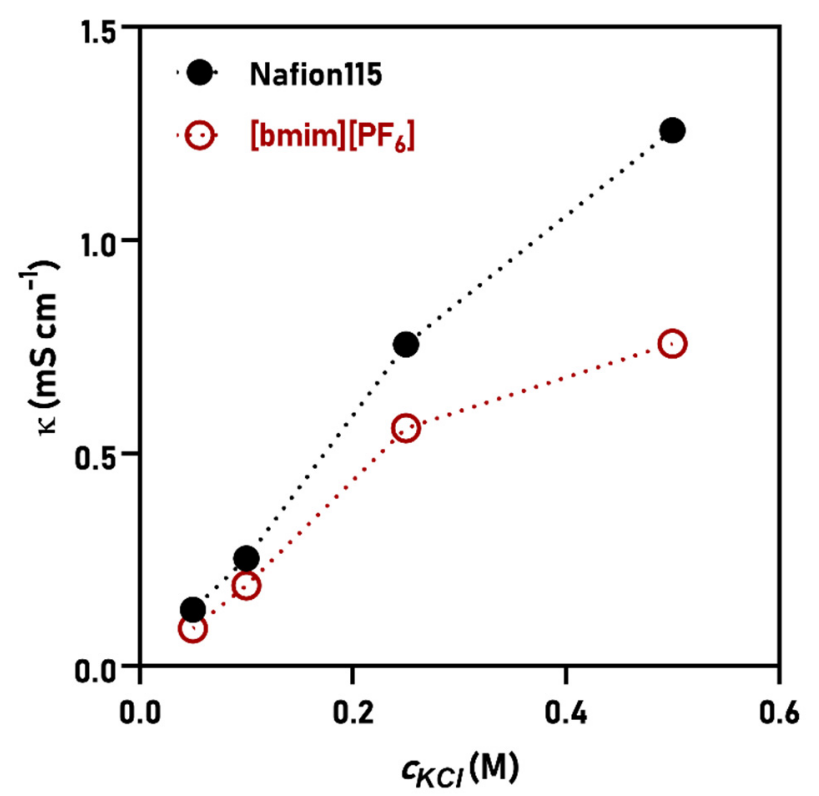

Figure 5. The dependence of conductivity on the electrolyte concentration in the cases of Nafion and [bmim][PF 6 -SILM.

Below that-i.e., by approaching real MFC conditions- the $\mathrm{k}$ of the two membranes tend to approach each other. Consequently, on the grounds of $k,\left[b^{2}\right.$ im $]\left[\mathrm{PF}_{6}\right]-S I L M$ becomes comparable to Nafion, which coincides with the result of our previous research, where impedance spectra unveiled similar impedances at high frequencies for Nafion and [bmim][PF 6 -SILM during MFC operation [21].

\section{Conclusions}

In this work, SILMs were fabricated using imidazolium-type ILs to investigate their proton and ion transfer traits. Based on the outcomes, the underlying mechanisms of proton transfer could be distinguished for imidazolium-type ILs with $\left[\mathrm{PF}_{6}\right]^{-}$and $\left[\mathrm{NTf}_{2}\right]^{-}$ anions and both SILMs were competitive with Nafion as shown by $\mathrm{k}_{\mathrm{H}+}$ and $\mathrm{D}_{\mathrm{H}+}$. The water permeation through the IL with $\left[\mathrm{PF}_{6}\right]^{-}$allows enhanced charge transfer kinetics, and in light of the transport numbers determined for $\mathrm{K}^{+}, \mathrm{Na}^{+}$, and $\mathrm{H}^{+}$, it seems to counteract the negative effects originating from the non-ideal ion transfer processes taking place in MFCs. The transport numbers obtained for $[\mathrm{bmim}]\left[\mathrm{PF}_{6}\right]-\mathrm{SILM}$ demonstrated that it may serve as 
an advantageous separator in real MFCs, thanks to its non-selective charge transfer (ion size proportional diffusion) and sufficient conductivity at low electrolyte concentrations.

Author Contributions: Conceptualization, methodology, investigation, formal analysis, data curation, writing-original draft preparation, and visualization by L.K., P.L.-S., and P.B. Supervision, project administration, and funding acquisition by K.B.-B. and N.N. All authors have read and agreed to the published version of the manuscript.

Funding: National Research, Development, and Innovation Office (NKFIH, Hungary) (FK 131409); National Research, Development, and Innovation Fund of Hungary (Project no. TKP2020-IKA-07; 2020-4.1.1-TKP2020).

Institutional Review Board Statement: Not Applicable.

Informed Consent Statement: Not applicable.

Data Availability Statement: Data associated with this research are mentioned in the article.

Acknowledgments: The support of the National Research, Development, and Innovation Office (NKFIH, Hungary) under grant number FK 131409 is acknowledged. This work was supported by the TKP2020-IKA-07 project financed under the 2020-4.1.1-TKP2020 Thematic Excellence Programme by the National Research, Development, and Innovation Fund of Hungary.

Conflicts of Interest: The authors declare no conflict of interest.

\section{References}

1. Logan, B.E.; Hamelers, B.; Rozendal, R.; Schröder, U.; Keller, J.; Freguia, S.; Aelterman, P.; Verstraete, W.; Rabaey, K. Microbial fuel cells: Methodology and technology. Environ. Sci. Technol. 2006, 40, 5181-5192. [CrossRef] [PubMed]

2. Logan, B.E. Exoelectrogenic bacteria that power microbial fuel cells. Nat. Rev. Microbiol. 2009, 7, 375-381. [CrossRef] [PubMed]

3. Oliot, M.; Galier, S.; Roux de Balmann, H.; Bergel, A. Ion transport in microbial fuel cells: Key roles, theory and critical review. Appl. Energy 2016, 183, 1682-1704. [CrossRef]

4. Welton, T. Ionic liquids: A brief history. Biophys. Rev. 2018, 10, 691-706. [CrossRef] [PubMed]

5. Wu, H.B.; Zhang, B.; Liu, S.H.; Chen, C.C. Flammability estimation of 1-hexyl-3-methylimidazolium bis(trifluoromethylsulfonyl) imide. J. Loss Prev. Process Ind. 2020, 66, 104196. [CrossRef]

6. Ahrenberg, M.; Beck, M.; Neise, C.; Keßler, O.; Kragl, U.; Verevkin, S.P.; Schick, C. Vapor pressure of ionic liquids at low temperatures from AC-chip-calorimetry. Phys. Chem. Chem. Phys. 2016, 18, 21381-21390. [CrossRef]

7. Clarke, C.J.; Clarke, C.J.; Bui-Le, L.; Hallett, J.P.; Licence, P. Thermally-stable imidazolium dicationic ionic liquids with pyridine functional groups. ACS Sustain. Chem. Eng. 2020, 8, 8762-8772. [CrossRef]

8. Mezzetta, A.; Becherini, S.; Pretti, C.; Monni, G.; Casu, V.; Chiappe, C.; Guazzelli, L. Insights into the levulinate-based ionic liquid class: Synthesis, cellulose dissolution evaluation and ecotoxicity assessment. New J. Chem. 2019, 43, 13010-13019. [CrossRef]

9. Keaveney, S.T.; Haines, R.S.; Harper, J.B. Ionic liquid solvents: The importance of microscopic interactions in predicting organic reaction outcomes. Pure Appl. Chem. 2017, 89, 745-757. [CrossRef]

10. Claus, J.; Sommer, F.O.; Kragl, U. Ionic liquids in biotechnology and beyond. Solid State Ion. 2018, 314, 119-128. [CrossRef]

11. Guglielmero, L.; Mezzetta, A.; Pomelli, C.S.; Chiappe, C.; Guazzelli, L. Evaluation of the effect of the dicationic ionic liquid structure on the cycloaddition of CO2 to epoxides. J. CO2 Util. 2019, 34, 437-445. [CrossRef]

12. Liu, H.; Liu, Y.; Li, J. Ionic liquids in surface electrochemistry. Phys. Chem. Chem. Phys. 2010, 12, 1685-1697. [CrossRef] [PubMed]

13. Liu, H.; Yu, H. Ionic liquids for electrochemical energy storage devices applications. J. Mater. Sci. Technol. 2019, 35, 674-686. [CrossRef]

14. Yan, X.; Anguille, S.; Bendahan, M.; Moulin, P. Ionic liquids combined with membrane separation processes: A review. Sep. Purif. Technol. 2019, 222, 230-253. [CrossRef]

15. Wang, J.; Luo, J.; Feng, S.; Li, H.; Wan, Y.; Zhang, X. Recent development of ionic liquid membranes. Green Energy Environ. 2016, 1, 43-61. [CrossRef]

16. Sasikumar, B.; Arthanareeswaran, G.; Ismail, A.F. Recent progress in ionic liquid membranes for gas separation. J. Mol. Liq. 2018, 266, 330-341. [CrossRef]

17. Hernández-Fernández, F.J.; De Los Ríos, A.P.; Mateo-Ramírez, F.; Juarez, M.D.; Lozano-Blanco, L.J.; Godínez, C. New application of polymer inclusion membrane based on ionic liquids as proton exchange membrane in microbial fuel cell. Sep. Purif. Technol. 2016, 160, 51-58. [CrossRef]

18. Hernández-Fernández, F.J.; Pérez de los Ríos, A.; Mateo-Ramírez, F.; Godínez, C.; Lozano-Blanco, L.J.; Moreno, J.I.; Tomás-Alonso, F. New application of supported ionic liquids membranes as proton exchange membranes in microbial fuel cell for waste water treatment. Chem. Eng. J. 2015, 279, 115-119. [CrossRef] 
19. Koók, L.; Nemestóthy, N.; Bakonyi, P.; Zhen, G.; Kumar, G.; Lu, X.; Su, L.; Saratale, G.D.; Kim, S.H.; Gubicza, L. Performance evaluation of microbial electrochemical systems operated with Nafion and supported ionic liquid membranes. Chemosphere 2017, 175, 350-355. [CrossRef]

20. Koók, L.; Nemestóthy, N.; Bakonyi, P.; Göllei, A.; Rózsenberszki, T.; Takács, P.; Salekovics, A.; Kumar, G.; Bélafi-Bakó, K. On the efficiency of dual-chamber biocatalytic electrochemical cells applying membrane separators prepared with imidazolium-type ionic liquids containing [NTf2]- and [PF6]- anions. Chem. Eng. J. 2017, 324, 296-302. [CrossRef]

21. Koók, L.; Kaufer, B.; Bakonyi, P.; Rózsenberszki, T.; Rivera, I.; Buitrón, G.; Bélafi-Bakó, K.; Nemestóthy, N. Supported ionic liquid membrane based on [bmim][PF6] can be a promising separator to replace Nafion in microbial fuel cells and improve energy recovery: A comparative process evaluation. J. Membr. Sci. 2019, 570, 215-225. [CrossRef]

22. Pendleton, J.N.; Gilmore, B.F. The antimicrobial potential of ionic liquids: A source of chemical diversity for infection and biofilm control. Int. J. Antimicrob. Agents 2015, 46, 131-139. [CrossRef] [PubMed]

23. Fang, C.; Kong, L.; Ge, Q.; Zhang, W.; Zhou, X.; Zhang, L.; Wang, X. Antibacterial activities of N-alkyl imidazolium-based poly (ionic liquid) nanoparticles. Polym. Chem. 2019, 10, 209-218. [CrossRef]

24. Cserjési, P.; Nemestóthy, N.; Bélafi-Bakó, K. Gas separation properties of supported liquid membranes prepared with unconventional ionic liquids. J. Membr. Sci. 2010, 349, 6-11. [CrossRef]

25. Harris, K.R.; Woolf, L.A.; Kanakubo, M. Temperature and pressure dependence of the viscosity of the ionic liquid 1-butyl-3methylimidazolium hexafluorophosphate. J. Chem. Eng. Data 2005, 50, 1777-1782. [CrossRef]

26. Harris, K.R.; Kanakubo, M.; Woolf, L.A. Temperature and pressure dependence of the viscosity of the ionic liquids 1-hexyl-3methylimidazolium hexafluorophosphate and 1-butyl-3-methylimidazolium BiS (trifluoromethylsulfonyl) imide. J. Chem. Eng. Data 2007, 52, 1080-1085. [CrossRef]

27. Ghasemi, M.; Wan Daud, W.R.; Ismail, M.; Rahimnejad, M.; Ismail, A.F.; Leong, J.X.; Miskan, M.; Ben Liew, K. Effect of pretreatment and biofouling of proton exchange membrane on microbial fuel cell performance. Int. J. Hydrog. Energy 2013, 38, 5480-5484. [CrossRef]

28. Zhang, X.; Cheng, S.; Wang, X.; Huang, X.; Logan, B.E. Separator characteristics for increasing performance of microbial fuel cells. Environ. Sci. Technol. 2009, 43, 8456-8461. [CrossRef]

29. Suransh, J.; Tiwari, A.K.; Mungray, A.K. Modification of clayware ceramic membrane for enhancing the performance of microbial fuel cell. Environ. Prog. Sustain. Energy 2020, 39, e13427. [CrossRef]

30. Guidoni, S.E.; Aldao, C.M. On diffusion, drift and the Einstein relation. Eur. J. Phys. 2002, 23, 395-402. [CrossRef]

31. Choi, J.H.; Moon, S.H. Structural change of ion-exchange membrane surfaces under high electric fields and its effects on membrane properties. J. Colloid Interface Sci. 2003, 265, 93-100. [CrossRef]

32. Harnisch, F.; Schröder, U.; Scholz, F. The suitability of monopolar and bipolar ion exchange membranes as separators for biological fuel cells. Environ. Sci. Technol. 2008, 42, 1740-1746. [CrossRef]

33. Koryta, J. Diffusion. Mass Transfer in Fluid Systems. J. Electroanal. Chem. Interfacial Electrochem. 1985, 194, 169-170. [CrossRef]

34. Agmon, N. The Grotthuss mechanism. Chem. Phys. Lett. 1995, 244, 456-462. [CrossRef]

35. Cukierman, S. Proton mobilities in water and in different stereoisomers of covalently linked gramicidin A channels. Biophys. J. 2000, 78, 1825-1834. [CrossRef]

36. Fortunato, R.; Afonso, C.A.M.; Reis, M.A.M.; Crespo, J.G. Supported liquid membranes using ionic liquids: Study of stability and transport mechanisms. J. Membr. Sci. 2004, 242, 197-209. [CrossRef]

37. Bakonyi, P.; Koók, L.; Rózsenberszki, T.; Tóth, G.; Bélafi-Bakó, K.; Nemestóthy, N. Development and application of supported ionic liquid membranes in microbial fuel cell technology: A concise overview. Membranes 2020, 10, 16. [CrossRef]

38. Kashin, A.S.; Galkin, K.I.; Khokhlova, E.A.; Ananikov, V.P. Direct observation of self-organized water-containing structures in the liquid phase and their influence on 5-(hydroxymethyl) furfural formation in ionic liquids. Angew. Chem. 2016, 55, 2161-2166. [CrossRef]

39. Domańska, U.; Rękawek, A.; Marciniak, A. Solubility of 1-alkyl-3-ethylimidazolium-based ionic liquids in water and 1-octanol. J. Chem. Eng. Data 2008, 53, 1126-1132. [CrossRef]

40. Dhar, B.R.; Lee, H.S. Membranes for bioelectrochemical systems: Challenges and research advances. Environ. Technol. 2013, 34, 1751-1764. [CrossRef] [PubMed]

41. Ranke, J.; Othman, A.; Fan, P.; Müller, A. Explaining ionic liquid water solubility in terms of cation and anion hydrophobicity. Int. J. Mol. Sci. 2009, 10, 1271-1289. [CrossRef]

42. Kato, H.; Nishikawa, K.; Koga, Y. Relative hydrophobicity and hydrophilicity of some "ionic liquid" anions determined by the 1-propanol probing methodology: A differential thermodynamic approach. J. Phys. Chem. B 2008, 112, 2655-2660. [CrossRef]

43. Zhou, G.; Jiang, K.; Wang, Z.; Liu, X. Insight into the behavior at the hygroscopicity and interface of the hydrophobic imidazoliumbased ionic liquids. Chin. J. Chem. Eng. 2021, 31, 42-55. [CrossRef]

44. Freire, M.G.; Santos, L.M.; Fernandes, A.M.; Coutinho, J.A.; Marrucho, I.M. An overview of the mutual solubilities of waterimidazolium-based ionic liquids systems. Fluid Phase Equilibria 2007, 261, 449-454. [CrossRef]

45. Han, Q.; Wang, X.; Bynre, N. Utilizing water activity as a simple measure to understand hydrophobicity in ionic liquids. Front. Chem. 2019, 7, 112. [CrossRef] [PubMed] 
46. Visser, A.E.; Reichert, W.M.; Swatloski, R.P.; Willauer, H.D.; Huddleston, J.G.; Rogers, R.D. Characterization of Hydrophilic and Hydrophobic Ionic Liquids: Alternatives to Volatile Organic Compounds for Liquid-Liquid Separations. ACS Symp. Ser. 2002, 818, 289-308.

47. Kamimura, A.; Shiramatsu, Y.; Murata, K.; Kawamoto, T. Solubility-switchable ionic liquids: A control of hydrophilicity and hydrophobicity using a protective group. Chem. Lett. 2018, 47, 1079-1081. [CrossRef]

48. Rollet, A.L.; Porion, P.; Vaultier, M.; Billard, I.; Deschamps, M.; Bessada, C.; Jouvensal, L. Anomalous diffusion of water in [BMIM][TFSI] room-temperature ionic liquid. J. Phys. Chem. B 2007, 111, 11888-11891. [CrossRef] [PubMed]

49. Handy, S.T.; Okello, M. The 2-position of imidazolium ionic liquids: Substitution and exchange. J. Org. Chem. 2005, 70, 1915-1918. [CrossRef]

50. Zaoui, A.; Mahendra, V.; Mitchell, G.; Cherifi, Z.; Harrane, A.; Belbachir, M. Design, Synthesis and Thermo-chemical Properties of Rosin Vinyl Imidazolium Based Compounds as Potential Advanced Biocompatible Materials. Waste Biomass Valoriz. 2020, 11, 3723-3730. [CrossRef]

51. De Eulate, E.A.; Silvester, D.S.; Arrigan, D.W.M. Void-assisted ion-paired proton transfer at water-ionic liquid interfaces. Angew. Chem. 2015, 54, 14903-14906. [CrossRef]

52. Yaghini, N.; Gómez-González, V.; Varela, L.M.; Martinelli, A. Structural origin of proton mobility in a protic ionic liquid/imidazole mixture: Insights from computational and experimental results. Phys. Chem. Chem. Phys. 2016, 18, 23195-23206. [CrossRef] [PubMed]

53. Martinelli, A.; Maréchal, M.; Östlund, Å.; Cambedouzou, J. Insights into the interplay between molecular structure and diffusional motion in 1-alkyl-3-methylimidazolium ionic liquids: A combined PFG NMR and X-ray scattering study. Phys. Chem. Chem. Phys. 2013, 15, 5510-5517. [CrossRef] [PubMed]

54. Koók, L.; Zitka, J.; Szakács, S.; Rózsenberszki, T.; Otmar, M.; Nemestóthy, N.; Bélafi-Bakó, K.; Bakonyi, P. Efficiency, operational stability and biofouling of novel sulfomethylated polystyrene-block-poly (ethylene-ran-butylene)-block-polystyrene cation exchange membrane in microbial fuel cells. Bioresour. Technol. 2021, 333, 125153. [CrossRef] [PubMed] 